\title{
Rock Magnetic and Palaeomagnetic Studies of British Speleothems
}

\author{
Andrew M. PERKINS and Barbara A. MAHER \\ School of Environmental Sciences, University of East Anglia, Norwich, Norfolk, NR4 7TJ, G.B.
}

(Received November 28, 1991; Revised June 15, 1992)

\begin{abstract}
The suitability of speleothems (secondary cave deposits) for palaeomagnetic use is being investigated. Previous workers have demonstrated that speleothems often carry a measurable and stable natural remanent magnetization (NRM). Speleothems may often be a more reliable source of palaeosecular variation (PSV) information than soft sediments. Our results demonstrate repeatable PSV records from two British stalagmites with overlapping growth periods. We present some preliminary rock magnetic data from speleothems which indicate a grain size difference between the magnetic grains in flowstones (laminar speleothems) and stalagmites (columnar speleothems). This has implications for the origin of the NRM. Detrital material is seen in speleothems but a chemical origin for the magnetization, possibly involving organic material in drip water, also seems likely, particularly in purer speleothems not subjected to coatings of detritus by flood events.
\end{abstract}

\section{Introduction: The Recorders of PSV}

Construction of geomagnetic palaeosecular variation (PSV) records has hitherto been carried out primarily using lake and shallow marine sediments and has yielded records from many global locations (e.g. TURNER and THOMPSON, 1981; CREER, 1982; CREER et al., 1986).

Other materials have been studied as potential PSV recorders. For example, spot-readings of PSV from archaeological materials such as pottery and fireplace bricks (e.g. AITKEN, 1974) and lava flows (e.g. ROBERTSON, 1986) have extended historical records. Cave sediments have also been examined (e.g. NOEL and ST.PIERRE, 1984; TURNER and LYONS, 1986) with the hope that, having a preservation potential exceeding that of any terrestrial deposit (THISTLEWOOD, 1991), they may provide long sequences of PSV over several levels in a cave system.

Speleothems are secondary deposits, usually of calcium carbonate, found within caves; they include stalagmites, stalactites and flowstones. Their use as recorders of PSV has been suggested in several studies (e.g. LATHAM et al., 1979, 1986, 1989; LATHAM, 1981; MoRINAGA et al., 1986, 1989) but despite good results their use in palaeomagnetic studies has, so far, been restricted. Speleothems have been used for magnetostratigraphy, in estimating valley incision rates (e.g. RowE et al., 1988), constraining the development of cave systems (e.g. HILL, 1987; PERKINS, 1991) and in palaeoclimatic studies (e.g. LAURITZEN et al., 1990). The mechanisms by which natural remanent magnetizations (NRMs) are acquired by speleothems are not well understood.

The purpose of this paper is to compare the potential of speleothems as recorders of PSV with that of soft sediments and to report preliminary magnetic results from some British speleothems, with the aim of identifying the magnetic carriers. In the light of our results, the possible origins for speleothem NRM are discussed.

\section{Problems with Lake Sediments and the Potential of Speleothems in PSV Studies}

Soft, unconsolidated sediments are not closed systems. Through a number of depositional and postdepositional processes (VEROSUB, 1977), they can be prone to information loss or gain. These problems are discussed below $(1-5 a)$ in conjunction with analogous situations in speleothems $(1-5 b)$. 


\section{1) Remanence acquisition time}

a) In the case of soft sediments, between sediment deposition and the point at which grains can no longer rotate (the lock-in depth), there is a time interval during which magnetic grains are able to follow the (changing) geomagnetic field (GMF). Thus, the remanence at a point within a core is not that of the ambient GMF in which the sediment was deposited; i.e. there is an acquisition time-lag.

b) From studies of speleothems, the remanences of samples from the top of active speleothems (i.e. those that are growing) have been found to be very close to the ambient GMF direction of the sampling site (e.g. LATHAM et al., 1979; MORINAGA et al., 1989). Speleothem remanence thus appears to have a negligible acquisition time-lag.

2) Sedimentary problems

a) During compaction of a soft sediment, water is expelled and may cause partial or full remobilization of the sediment during which magnetic grains could re-align with a "new" GMF. Matrix composition (LU et al., 1990) and compaction (ARASON and LEVI, 1990) are believed to cause inclination shallowing. Processes such as turbidity currents and slumping may also operate.

b) Speleothems are not subject to compaction or slumping. Dissolution, cessation of growth or movement (due, perhaps, to substrate instability) during growth in speleothems can usually be identified in section as disconformities of growth laminae. LATHAM et al. (1987) note that speleothem deposition is not constant for long periods of time and suggest that speleothem derived PSV records may have to be constructed in segments. Low NRM intensities are a problem in pure speleothems, but with careful choice of sampling site this difficulty can be avoided. The size of speleothems dictates the number of samples available. Sometimes only one sample per horizon is achievable (e.g. stalagmite SJLS of LATHAM et al., 1989). If intensities are sufficiently high, sub-sampling into thinner samples is possible (e.g. MORINAGA et al., 1989) and offers a much greater PSV resolution.

3) Diagenetic problems

a) KING and CHANNEL (1991) review recent work on the reduction diagenesis of magnetite in soft sediments. Such situations may cause partial overprinting or even destruction of an existing remanence.

b) Within speleothems, the only diagenetic problem is that of recrystallization, though in young calcite speleothems this is uncommon. If it occurs, it is detectable in thin section by crystallographic changes (LATHAM et al., 1989). Such samples are therefore not suitable for palaeomagnetic study.

4) Biological problems

a) Sediments provide a habitat for a variety of organisms. The extent to which burrowing takes place within sediment is not well known but cannot be ignored because it will cause some degree of homogenization of the magnetic, pollen and carbon content. It is now known that "magnetic" bacteria are present in a wide range of environments (e.g. LOVLEY et al., 1987; FRANKEL and BLAKEMORE, 1989). Many biogenic magnetites are of single-domain grain size. A contribution from these phases to a sedimentary remanence will be more stable than contributions from detrital multi-domain phases. Biogenically derived magnetite could, therefore, overprint a sedimentary remanence.

b) In contrast, no organisms are known to burrow into sub-aerial speleothems. An aim of the present work is to identify whether or not biogenic magnetite is present in speleothems.

5) Sampling problems

a) The techniques involved in sampling sediments inevitably cause disturbance, some of which can be minimized by sub-sampling from large cores, although some sediment shear still takes place when sample boxes are inserted. Azimuthal control is often not possible - only relative core to core declination matching is sometimes possible. "Cork-screwing" and non-vertical coring can also introduce errors.

b) No disturbance of remanence arises from sampling speleothems because they are solid rock. They can be accurately orientated in-situ, providing both inclination and declination data. Errors due to misalignment in sub-sampling by rock-saws/coring are extremely small (see for example $\alpha_{95}$ statistics of coeval samples in LATHAM et al., 1982, 1986).

6) Dating problems

a) The presence of "fossil-carbon" (e.g. LUND and BANERJEE, 1979) in many sediments is an 
established problem. Radioisotope migration due to fluid movements caused by sedimentary processes and bioturbation can also lead to incorrect radiocarbon dates. BARD et al.'s (1990) calibration of the ${ }^{14} \mathrm{C}$ time scale for the last $30 \mathrm{ka}$ will now help to counter variations in atmospheric ${ }^{14} \mathrm{C} /{ }^{12} \mathrm{C}$ levels.

b) If recrystallization does not occur in speleothems, radioisotope migration cannot occur. For speleothems dated by U-series methods, the major problem which can arise is that of low uranium content-though this problem has been reduced by the development of mass-spectrometric dating techniques (e.g. Li et al., 1989). Contamination by detrital thorium (e.g. LATHAM et al., 1989) can be corrected for (SCHWARCZ and LATHAM, 1989; BISCHOFF and FITZPATRICK, 1991; PRZYBYLOWICZ et al., 1991).

The significance of each of the above points for sedimentary PSV records is not known. HANNA and VEROSUB (1989) found that the agreement between the PSV records from Fish Lake (VEROSUB et al., 1986) and a stalagmite from Vancouver Island (LATHAM et al., 1982) was better than that between 15 other lake sediment records from western North America. HANNA and VEROSUB (op. cit.) concluded that radiocarbon dating and other errors probably distorted many of the lake sediment records.

For speleothems, the potential effects of many of the problems noted above are reduced. Therefore, speleothems may offer a better source of PSV information than sediments.

\section{Palaeo- and Rock Magnetic Properties of Speleothems}

\subsection{Introduction}

If speleothems are to provide a more reliable source of PSV information than soft sediments, then it is necessary to demonstrate that speleothem records are repeatable between contemporaneous deposits and that their remanences are stable (which has been shown by previous workers). It is also important to understand the origin and nature of the magnetic carriers. The present work aims to address these points and our initial results are set out below.

\subsection{Repeatable PSV records between speleothems}

The nature of the cave environment is such that until a speleothem is dated absolutely, it is not possible to infer that adjacent speleothems of similar dimensions are of the "same" age. MORINAGA et al. (1987a) have tentatively correlated the PSV records of two stalagmites from the same cave and MORINAGA et al. (1985) have suggested a possible correlation between two stalagmite records from different locations in Japan. In neither case, however, were the speleothems dated absolutely.

LATHAM et al. (1979) reported a record from a stalagmite (TS) collected from Yorkshire (England) spanning 11.3 to $7.5 \mathrm{ka}$ (LATHAM, 1981). We have collected another stalagmite (90-TS2) from the same location and have studied its palaeomagnetism.

90-TS2 had been broken off by other cavers but could be placed back into position for orientation. It was $34 \mathrm{~cm}$ high and approximately $15 \mathrm{~cm}$ in diameter throughout its length. The bottom few centimetres had a complex stratigraphy and were deemed unsuitable for palaeomagnetic analysis.

During preparation, 90-TS2 shattered in places and had to be glued back together. Consequently the number of samples available was reduced in order to avoid sampling from glued areas. A total of 98 samples were recovered.

A noticeable growth hiatus exists at $1.5 \mathrm{~cm}$ from the top. This is associated with an increase in magnetic intensity above, a change in remanence direction (see Fig. 1) and a striking difference in appearance from creamy coloured calcite below to alternating creamy and translucent brown calcite above. LATHAM et al. (1979) observed a similar phenomenon in stalagmite TS. The remanence direction for the very top of TS was almost coincident with the present day GMF in Yorkshire, which led these authors to believe the top was of recent origin. The mean direction from the top of 90-TS 2 is Inc. $66.6^{\circ}$, Dec. $12.1^{\circ} \mathrm{W}\left(\alpha_{95}=6.3^{\circ}, n=6\right)$ whilst the present day GMF in Yorkshire is Inc. $68.5^{\circ}$, Dec $6.1^{\circ} \mathrm{W}$. Thus, we believe the top $1.5 \mathrm{~cm}$ in $90-\mathrm{TS} 2$ is also of recent origin.

Stalagmite 90 -TS2 is generally very pure; as a consequence magnetic intensity is low. However, the 

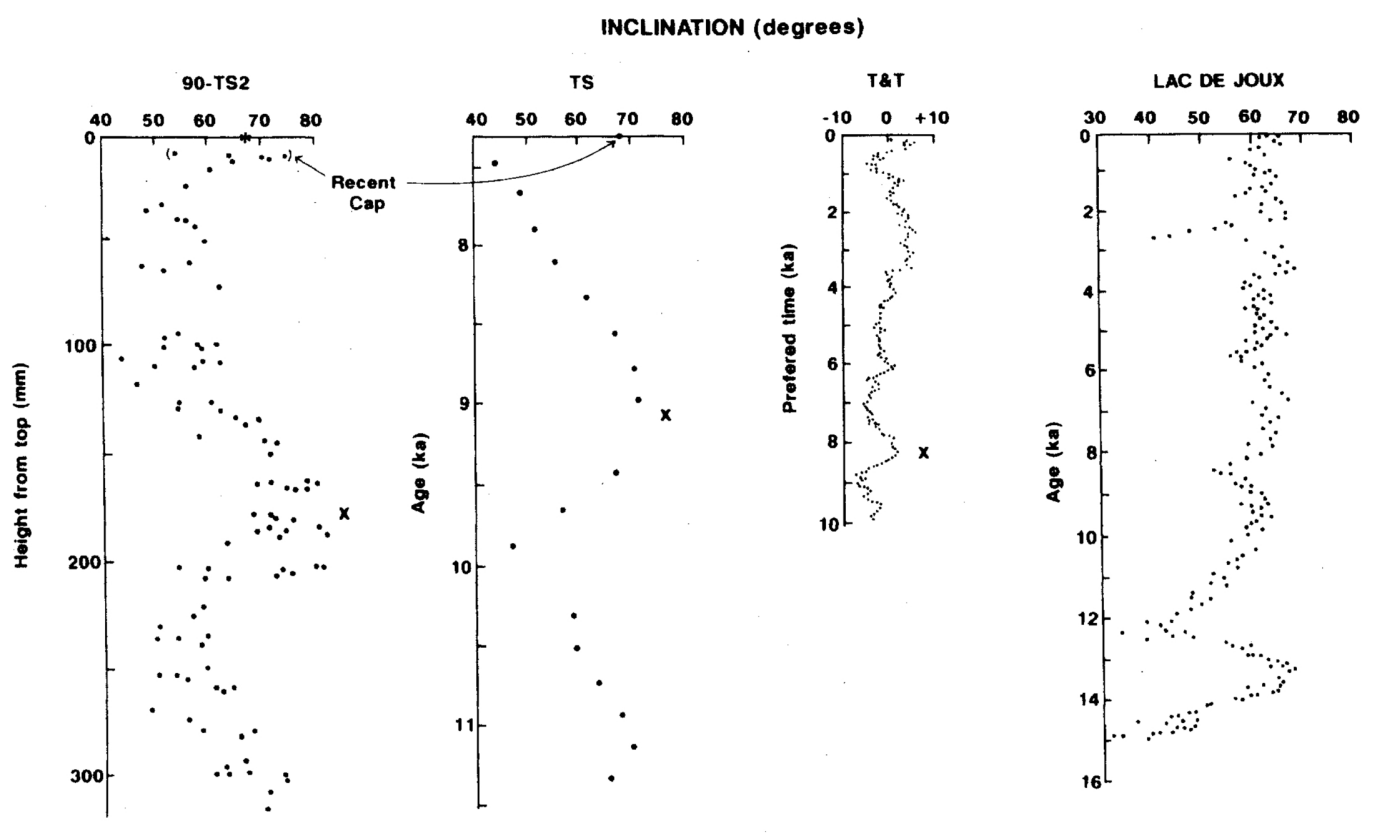

(a)

DECLINATION (degrees)
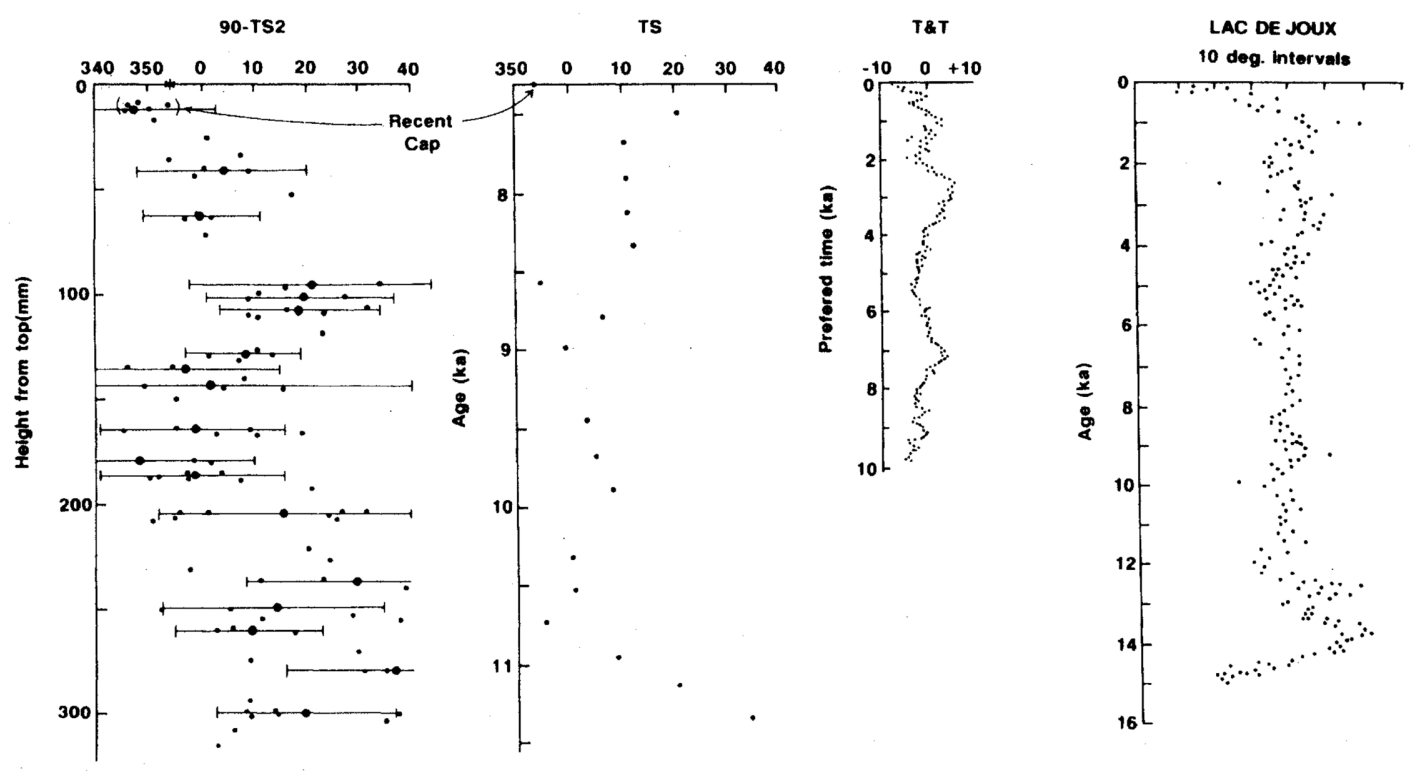

(b)

Fig. 1. Palaeomagnetic results of 90-TS2, TS (LATHAM et al., 1979), T\&T (the "averaged transformed" British PSV curve of TURNER and THOMPSON, 1981) and Lac de Joux (CREER et al., 1980). An averaged declination curve for 90 -TS2 is shown as larger points and associated error bars. The present-day field for the collection site of 90-TS2 is denoted by an asterisk. 
(a)
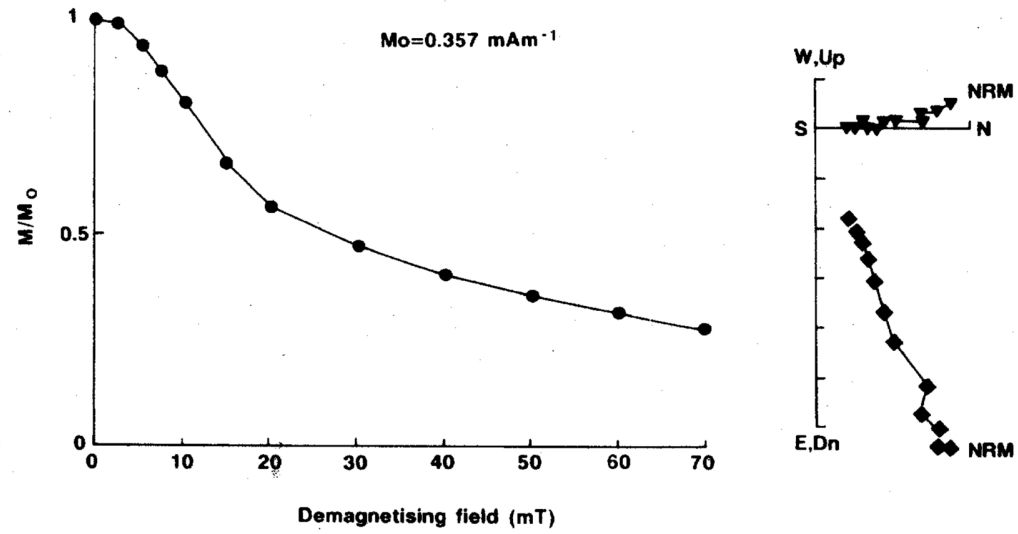

(b)

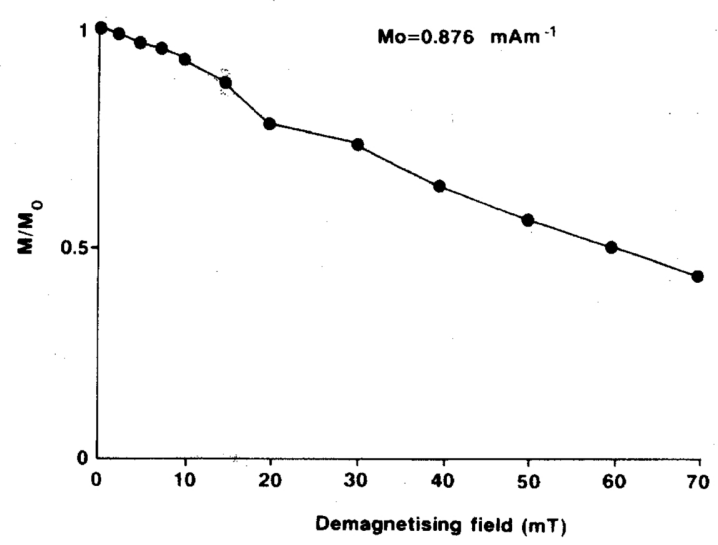

$0.052 \mathrm{mAm}^{-1}$

(c)
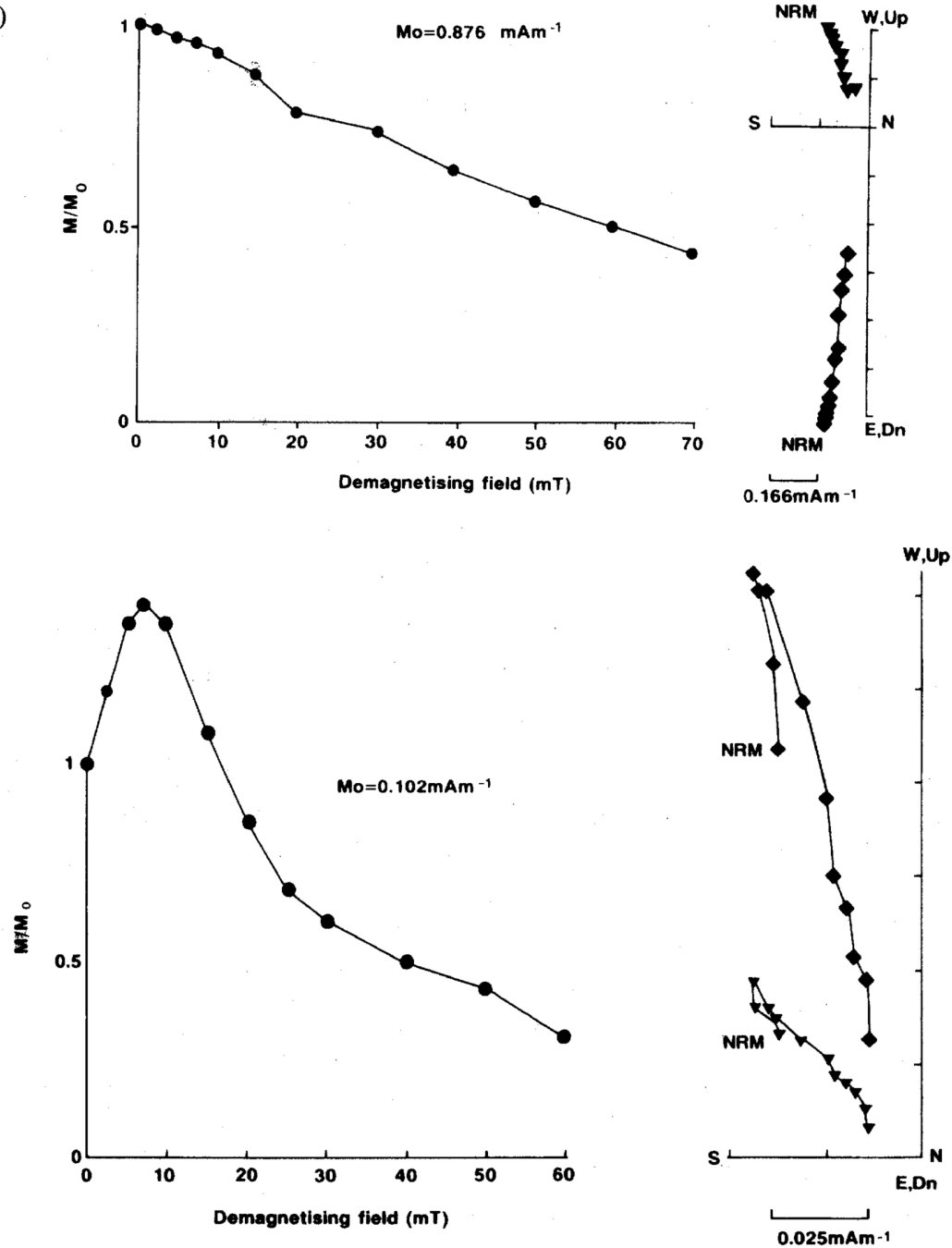

Fig. 2. Alternating field demagnetization behaviour of three speleothems. a) Sample D1R, from stalagmite 90-TS2, Yorkshire, England. b) Sample EHS4/2, from a stalagmite from Derbyshire, England. c) Sample EHF3/5, from a flowstone from Derbyshire, England. 
basal areas and in lateral samples, thin section analysis reveals some quartz dominated detritus with some organic matter and opaque grains. Grain sizes are $<0.3 \mathrm{~mm}$ in diameter and average around $0.1 \mathrm{~mm}$. Grains are generally sub-rounded and of moderate sphericity. Organic matter is present throughout the stalagmite in varying amounts. Higher magnetic intensities seem to be associated with higher concentrations of organic material where detritus is not microscopically visible (such as the top $1.5 \mathrm{~cm}$ ).

Figure 1 shows the two palaeomagnetic records from stalagmites TS (LATHAM et al., op. cit.) and 90TS2 (this study), along with the lake sediment record from Lac de Joux (CREER et al., 1980) and the "average transformed" British record of TURNER and THOMPSON (1981). Correlation between the inclination records of the two stalagmites is good. An averaging of the declination record of 90-TS2 (shown as larger points and associated error bars) also shows a good correlation with TS. We believe the inclination peak X correlates in both stalagmites and with TURNER and THOMPSON's (1981) record. This may be the same feature between $9 \mathrm{ka}$ and $10 \mathrm{ka}$ in the Lac de Joux record. Our stalagmite is yet to be dated absolutely.

\subsection{Stability of speleothem NRMs}

Most work involving speleothem magnetism has included analyses of NRM stability. Median destructive fields (MDFs) are often in excess of 20-30 mT suggesting the presence of a ferrimagnetic remanence carrier. Removal of viscous components at low fields leaves a stable single component of magnetization. Figure 2 shows the alternating field (AF) demagnetization behaviour of three of our

a)

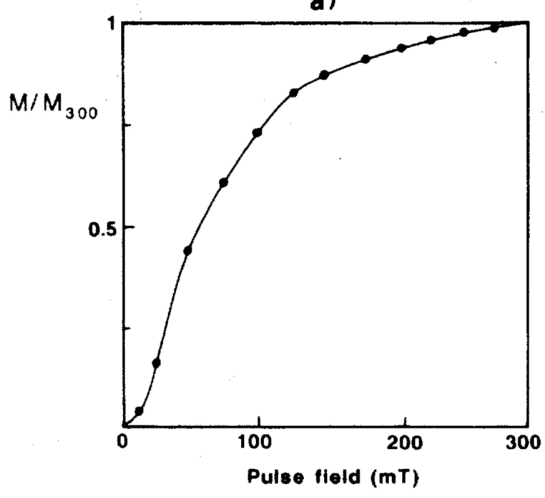

c)

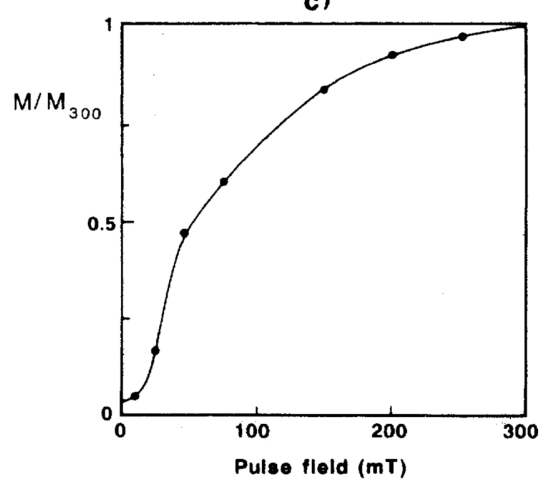

b)

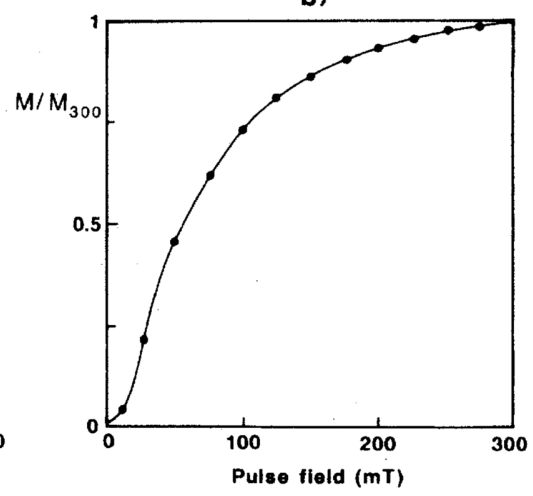

d)

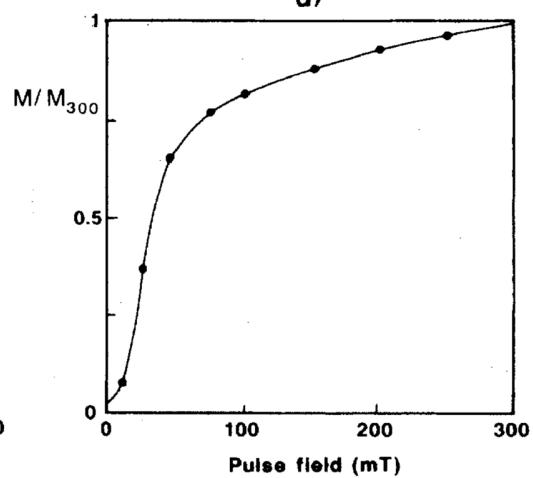

Fig. 3. Isothermal remanent magnetization acquisition curves of four speleothems. a) Sample E19R, from stalagmite $90-\mathrm{TS} 2$, Yorkshire, England. b) Sample C2, from stalagmite NYS2, Yorkshire, England. c) Sample EHS3/3, from a stalagmite, Derbyshire, England. d) Sample EHF1/26, from a flowstone, Derbyshire, England. 
samples. Hard, stable, single components of magnetization remaining after the removal of viscous overprints, suggests the presence of fine grained, ferrimagnetic, remanence carriers.

\subsection{Mineralogy of magnetic phases}

Published literature on the magnetic phases contained within speleothems suggests that magnetite or titanomagnetite is the dominant phase (e.g. LATHAM et al., 1979, 1982, 1986, 1987, 1989; MORINAGA et al., 1986; NOEL, 1990). LATHAM et al.(1989) suggest, from Mössbauer spectroscopy, that detrital maghemite and pyrrhotite may be present in some Mexican speleothems. LAURITZEN et al. (1990) infer a detrital magnetite/maghemite remanence carrier in a Norwegian flowstone though they give no evidence for this conclusion. MORINAGA et al. (1986) and NOEL (1990) suggest that haematite may play a minor role in their Japanese and Chinese speleothems, respectively.

In the majority of British speleothems we have examined a ferrimagnetic phase is dominant. Figure 3 shows the acquisition of isothermal remanent magnetization (IRM) by four speleothems. Figures 3(a)(c) are stalagmites from different localities. These show very similar acquisition curves. Figure 3(d) shows the behaviour of a flowstone which, although from the same locality as stalagmite EHS3 (Fig. 3(c)), displays a steeper initial gradient of acquisition. This reflects differences between the magnetic phases of
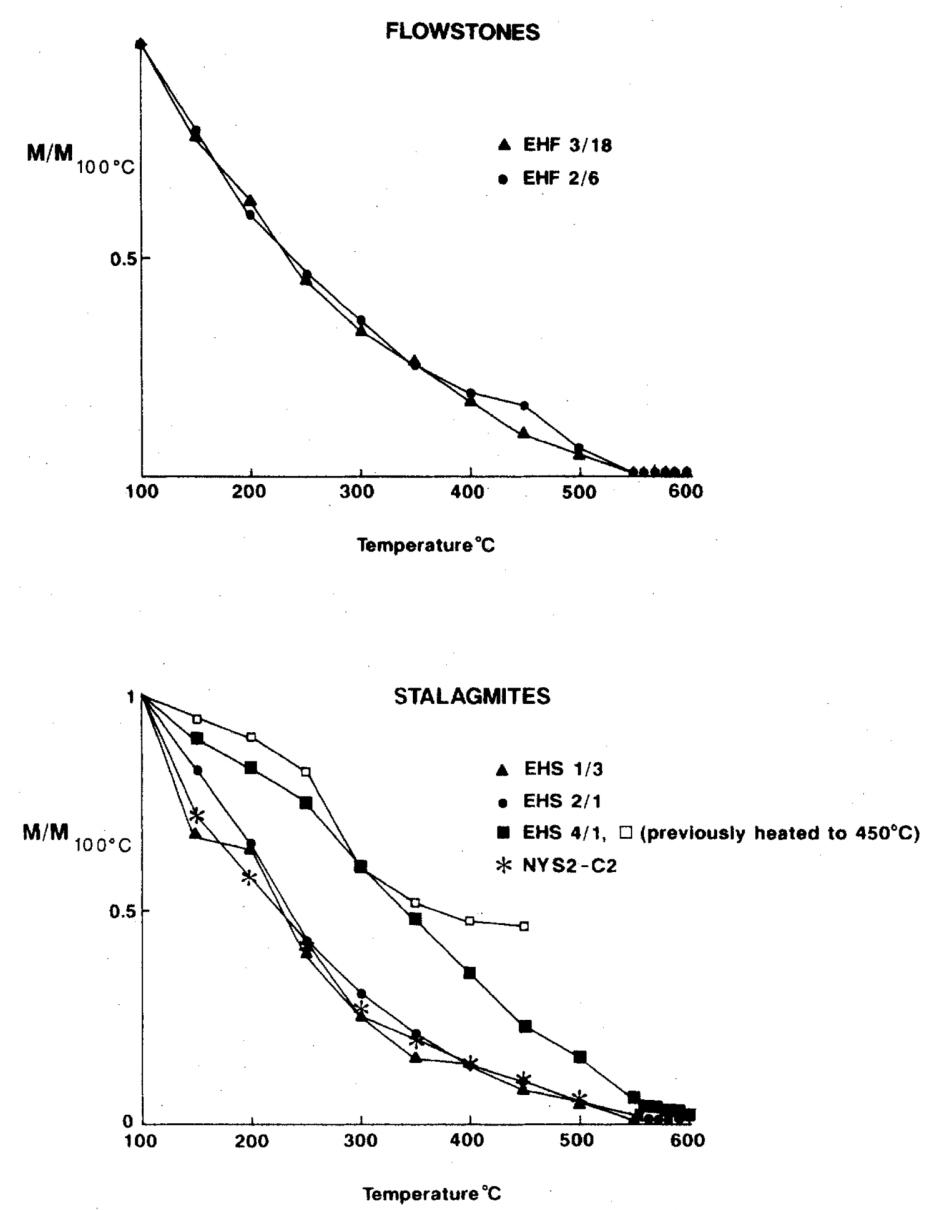

Fig. 4. Thermal demagnetization curves of speleothems subjected to an IRM of $300 \mathrm{mT}$. Top: Flowstone samples. Below: Stalagmite samples. 
flowstones and stalagmites (this is further discussed in Subsection 3.5). Neither flowstones nor stalagmites are completely saturated by $300 \mathrm{mT}$. At $1 \mathrm{~T}$, intensities increase by an additional $10-15 \%$ suggesting that a higher coercivity phase exists in addition to a dominant ferrimagnetic component. Thermal demagnetization of NRMs suggests that the remanence is carried by the ferrimagnetic component. Thermal demagnetization of a number of samples subjected to an IRM of $300 \mathrm{mT}$ suggests that the ferrimagnetic phases are magnetite (Fig. 4). LATHAM et al. (1979) report TS samples saturating around $300 \mathrm{mT}$, whilst our 90-TS2 samples are not completely saturated at this level (Fig. 3(a)). Reasons for this are suggested in Section 4.

We have also identified a small number of speleothems with a high proportion of higher coercivity components which occasionally dominate the NRM. These results will be reported elsewhere.

\subsection{Magnetic grain-size studies}

So far, little work has been carried out to determine the grain size of magnetic phases in speleothems. The stability of speleothem NRM to AF demagnetization would suggest that grain sizes are probably within the single domain size range. Our studies on acquisition and AF demagnetization of anhysteretic remanences in speleothems reveal an apparent grain size difference in ferrimagnetic phases between stalagmites and flowstones (Fig. 5). Speleothems in which a ferrimagnetic component is not dominant do not conform to these observations. MAHER's (1988) work on very fine grained synthetic magnetites, showed the sensitivity of the ratio $\chi_{\mathrm{ARM}} / \mathrm{SIRM}$, to grain sizes within the sub-micron range. $\left(\chi_{\mathrm{ARM}}\right.$ is the mass specific ARM per unit of steady field.) Applying this ratio to speleothems in which the dominant magnetic phase is a ferrimagnet, data for flowstone samples plot in a different area to stalagmite samples (Fig. 5). Our classification of the samples into clean and dirty is based solely on visual examination (by

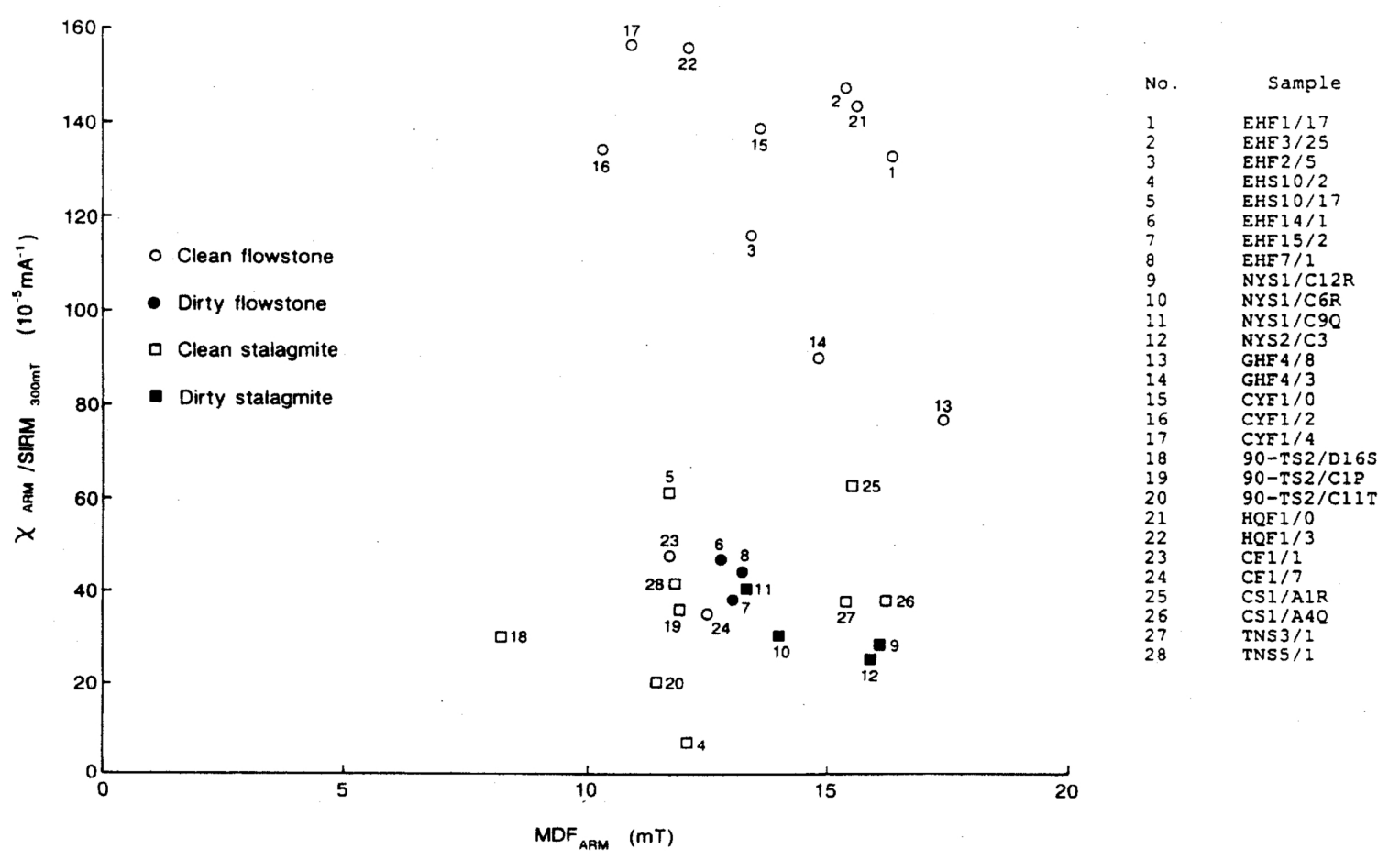

Fig. 5. Plot of $\chi_{\mathrm{ARM}} / \mathrm{SIRM}_{(300 \mathrm{mT})}$ vs $\mathrm{MDF}_{\mathrm{ARM}}$ for speleothem samples. ARM's were grown with a peak AF field of $80 \mathrm{mT}$ and a steady field of $0.08 \mathrm{mT}$. Sample names should be read as specimen/sample, where $\mathrm{F}$ or $\mathrm{S}$ in the specimen name denotes flowstone or stalagmite respectively. 
eye) for detrital content. We are presently conducting more detailed optical studies. These data do, however, suggest a relationship between speleothem morphology and ferrimagnetic grain size.

\section{The Origin of Speleothem NRMs}

Drawing on both published data and the data presented here, some insights into the origins of speleothem NRM may be gained.

Speleothems may acquire a detrital remanent magnetization (DRM), with detrital grains being incorporated into the speleothem as it grows (e.g. LATHAM et al., 1986, 1989). Such detritus may be derived from either cave sediment deposited onto speleothems during floods or carried from soil profiles in drip-water. If a DRM is solely responsible for NRM, then stalagmites (or flowstones) from different localities could be expected to have different magnetic properties according to the local detrital input to the cave. However, the results presented in Fig. 5 suggest this is not the case. The flowstones and stalagmites have been collected from widely different localities in Britain, yet they cluster together on the diagram. Conversely, flowstones and stalagmites from the same locality plot in different areas of the diagram (e.g. samples 1-8 from Eldon Hill (EH). Nos. 6, 7 and 8 are dirty flowstones).

Detrital magnetite has been observed in thin sections (LATHAM et al., 1982, 1986) and so a DRM must exist to some extent. However, another mechanism must account for the apparent grain size difference noted here and also for speleothems that carry an NRM but in which no detrital material is evident (for example, the upper parts of 90-TS2). LATHAM et al. (1979) found that specimens taken from steeply dipping flowstones and the (sub-vertical) sides of stalagmites had remanences free from depositional effects; i.e. their remanences were coincident with remanences of coeval horizontal specimens, even when detrital material was present. This has been found to be the case in all of their subsequent studies. We have found that lateral samples from stalagmite $90-\mathrm{TS} 2$ also show no evidence of a depositional effect. Hence, a remanence acquisition mechanism must account for this unexpected absence of a depositional error.

LATHAM (op. cit.) observed an association of measurable NRMs with organic matter even where detrital material was absent in thin-section. This also appears to be the case with 90-TS2. LATHAM et al. (1989) suggested that iron may be complexed with organic material and that when calcite precipitation takes place to form the speleothem, some iron is released in a reduced state allowing magnetite to form. MORINAGA et al. (1987b) attempted to model NRM acquisition in speleothems using a mixture of cave sediment and molten sodium thiosulphate. This mixture was allowed to drip onto various surfaces and crystallize. The relevance of the chemistry and the temperature at which sodium thiosulphate crystallizes $\left(48.5^{\circ} \mathrm{C}\right)$ in simulating cave conditions is, however, questionable.

On the basis of our preliminary rock magnetic data, we suggest that the magnetism in speleothems is (some form of) a CRM, with a DRM component present in dirty specimens. This would help explain the overlap of the dirty flowstones into the stalagmite "area" (Fig. 5). This may also be the reason for the slightly different behaviour of stalagmites TS (LATHAM et al., 1979) and 90-TS2 (this study) in terms of IRM saturation; i.e. the respective samples analysed may have possessed slightly different proportions of detrital magnetic phases.

On the basis of i) an apparent association of organic matter with magnetic intensity in detritus free speleothems and ii) a relationship between ferrimagnetic grain size and speleothem morphology, then the CRM would appear to be a function involving the presence or absence of organic matter and also the thickness and residence time of the water film on the surface of the speleothem.

\section{Summary and Conclusion}

A suite of potential problems are associated with soft sediments. Compaction, diagenesis, lack of consolidation and the fact that they are open-systems can reduce the reliability of PSV records derived from them. A few workers have shown that speleothems are, in many respects, potentially better sources of PSV information. 
PSV records appear to be repeatable between contemporaneous speleothems. Speleothem remanence is often, though not always, carried by very fine grained ferrimagnets. Where ferrimagnets are present, they are magnetites. A grain size difference according to speleothem form seems to be evident for the ferrimagnetic phases carried by clean specimens. The origin and nature of speleothem remanence is not yet fully understood, though a chemical remanent magnetization (CRM), possibly associated with the deposition of organic material, seems to be present. A component of magnetization due to detrital magnetic phases exists in some speleothems but its importance in purer samples is probably limited.

\section{Cautionary Note}

Speleothems and other cave formations are objects of significant aesthetic value to many people and their (permanent) removal and subsequent destruction must be given careful forethought. Limestone quarries, in which cave systems have been breached, are potential sources of speleothems, which would otherwise have been destroyed. Sampling from such sites is preferable to the destruction of speleothems in other cave systems. If speleothems from caves unthreatened by quarrying are to be sampled, preference should always be given to broken and/or inconspicuous specimens, or to material which has been buried by rock fall or other sediments.

The authors would like to thank Drs. Alf Latham and Laurence Thistlewood for assistance in collection of 90TS2 and subsequent discussions; Dr. Peter Smart for involvement in the Eldon Hill Quarry project; Members of UEA Fell and Cave Club for assistance underground. This paper benefited from the reviews of Dr. David Robertson and an anonymous referee. AMP is financed by a NERC Research Studentship No. GT4/89/GS/030 and additional support from his parents.

\section{REFERENCES}

Aitken, M. J., Physics and Archaeology, Oxford, Clarendon Press, 1974.

ARAson, P. and S. LEVI, Compaction and inclination shallowing in deep-sea sediments from the Pacific Ocean, J. Geophys. Res., 95, 4501-4510, 1990 .

BARD, E., B. HAmelin, R. G. Fairbanks, and A. ZindLer, Calibration of the ${ }^{14} \mathrm{C}$ timescale over the past 30,000 years using mass spectrometric U/Th ages from Barbados corals, Nature, 345, 405-410, 1990.

Bischoff, J. L. and J. A. FitzPATRICK, U-series dating of impure carbonates: An isochron technique using total-sample dissolution, Geochim. et Cosmochim. Acta, 55, 543-554, 1991.

CREER, K. M., Lake sediments as recorders of geomagnetic field variations-applications to dating post-Glacial sediments, Hydrobiologia, 92, 587-596, 1982.

Creer, K. M., T. E. Hogg, P. W. Readman, and C. Reynaud, Palaeomagnetic secular variation curves extending back to 13.4 ka BP, recorded by sediments deposited in Lac de Joux, Switzerland. Comparison with U.K. records, J. Geophys., 48, 139$147,1980$.

Creer, K. M., G. Smith, P. Tucholka, E. Bonifay, N. Thouveny, and E. Truee, A preliminary palaeomagnetic study of the Holocene and late Würmian sediments of Lac du Bouchet (Haute-Loire, France), Geophys. J. R. astr. Soc., 86, 943-964, 1986.

Frankel, R. B. and R. P. Blakemore, Magnetite and magnetotaxis in microorganisms, Bioelectromagnetics, 10, $223-237,1989$.

HANNA, R. L. and K. L. Verosub, A review of lacustrine palaeomagnetic records from western North America: 0-40000 years BP, Phys. Earth Planet. Int., 56, 76-95, 1989.

Hill, C. A., Geology of Carlsbad Cavern and other caves in the Guadalupe Mountains, New Mexico and Texas, Bull. 117, New Mexico Bureau of Mines and Minerals Resources, 1987.

KING, J. W. and J. E. T. ChANNEL, Sedimentary magnetism, environmental magnetism and magnetostratigraphy, Rev. Geophys., supplement, 358-370, 1991.

Latham, A. G., Palaeomagnetism, rock magnetism and U-Th dating of speleothem deposits, Unpubl. Ph.D. Thesis, 507 pp., McMaster Univ., Hamilton, Ontario, Canada, 1981.

Latham, A. G., H. P. Schwarcz, D. C. Ford, and G. W. Pearce, Palaeomagnetism of stalagmite deposits, Nature, 280, 383$385,1979$.

Latham, A. G., H. P. Schwarcz, D. C. Ford, and G. W. Pearce, The palaeomagnetism and U-Th dating of three Canadian speleothems: evidence for westward drift, 5.4-2.1 ka B.P., Can. J. Earth Sci., 19, 1985-1995, 1982.

LATham, A. G., H. P. SCHWARCZ, and D. C. FORD, The palaeomagnetism and U-Th dating of Mexican stalagmite DAS2, Earth Planet. Sci. Lett., 79, 195-207, 1986.

LATham, A. G., H. P. SChWARCZ, and D. C. FoRD, Secular variation of the Earth's magnetic field from 18.5 to 15.0 ka B.P., as recorded in a Vancouver Island stalagmite, Can. J. Earth Sci., 24, 1235-1241, 1987. 
Latham, A. G., D. C. Ford, H. P. Schwarcz, and T. Birchall, Secular variation from Mexican stalagmites: their potential and problems, Phys. Earth Planet. Int., 56, 34-48, 1989.

Lauritzen, S. E., R. LøVlie, D. MoE, and E. ØstbYe, Palaeoclimate deduced from a multidisciplinary study of a half-millionyear-old stalagmite from Rana, Northern Norway, Quat. Res., 34, 306-316, 1990.

Li, W.-X., J. Lundberg, A. P. Dickin, D. C. Ford, H. P. Schwarcz, R. McNutt, and D. Williams, High-precision massspectrometric uranium-series dating of cave deposits and implications for palaeoclimate studies, Nature, 339, 534-536, 1989.

Lovley, D. R., J. F. Stolz, G. L. NoRD, and E. J. P. Phillips, Anaerobic production of magnetite by a dissimilatory iron-reducing microorganism, Nature, 330, 252-254, 1987.

LU, R., S. K. BANERJEE, and J. MARVIN, Effects of clay mineralogy and the electrical conductivity of water on the aquisition of DRM in sediments, J. Geophys. Res., 95, 4531-4538, 1990.

Lund, S. P. and S. K. BANerJee, Palaeosecular variations from lake sediments, Rev. Geophys. Space Phys., 17, $244-249,1979$.

MAHER, B. A., Magnetic properties of some synthetic sub-micron magnetites, Geophys. J., 94, 83-96, 1988.

Morinaga, H., H. INOKUCHI, K. YASKAWA, M. IKEYA, T. MikI, and M. KuSAKABE, Palaeomagnetism, palaeoclimatology and ESR dating of stalagmite deposits, in ESR Dating and Dosimetry, edited by M. Ikeya and T. Miki, pp. 31-37, 1985.

MorinaGa, H., H. INOKUCHI, and K. YASKAWA, Magnetization of a stalagmite in Akiyoshi Plateau as a record of the geomagnetic secular variation in west Japan, J. Geomag. Geoelectr., 38, 27-44, 1986.

MorinAGA, H., H. INOKUCHI, and K. YASKAWA, Secular variation of the Geomagnetic field deduced from palaeomagnetism of stalagmites in Japan, Rock Magn. Palaeogeophys., 14, 18-22, 1987a.

Morinaga, H., M. Kamino, H. InOKUCHI, and K. YASKAWA, Remanent magnetization of synthetic stalagmites, Rock Magn. Palaeogeophys., 14, 13-17, 1987b.

Morinaga, H., H. INOKUCHI, and K. YASKAWA, Palaeomagnetism of stalagmites (speleothems) in S. W. Japan, Geophys. J., 96, $519-528,1989$.

NoEL, M., Palaeomagnetic and archaeomagnetic studies in the caves of Guangxi, Cave Sci., 17, 73-76, 1990.

NoEL, M. and S. ST.PIERRE, The palaeomagnetism and magnetic fabric of cave sediments from Grønligrotta and Jordbrugrotta, Norway, Geophys. J. Roy. astr. Soc., 78, 231-239, 1984.

Perkins, A. M., Magnetostratigraphy of cave sediments and speleothems from Derbyshire, England (abstract), An. Geophys., 9 (supplement), C81, 1991.

Przybylowicz, W., H. P. Schwarcz, and A. G. Latham, Dirty Calcites 2. Uranium-series dating of artificial calcite-detritus mixtures, Chem. Geol. (Isotope Geoscience), 86, 161-178, 1991.

Robertson, D. J., A palaeomagnetic study of Rangitoto Island, Auckland, New Zealand, N.Z. J. Geol. Geophys., 29, 405-411, 1986.

Rowe, P., T. Austin, and T. Atkinson, The Quaternary evolution of the British south Pennines from Uranium-series and palaeomagnetic data, Ann. Soc. geol. Belgique, 111, 97-106, 1988.

Schwarcz, H. and A. G. LATHAM, Dirty Calcites 1: Uranium-series dating of contaminated calcite using leachates alone, Chem. Geol. (Isotope Geoscience), 80, 35-43, 1989.

Thistlewood, L., A palaeomagnetic study of clastic sediments from Peak Cavern, Derbyshire, England, Unpubl. Ph.D. Thesis, 177 pp., Univ. of Sheffield, England, 1991.

Turner, G. M. and R. G. Lyons, A palaeomagnetic secular variation record from c. 120,000 year old New Zealand cave sediments, Geophys. J. Roy. astr. Soc., 87, 1181-1192, 1986.

TuRner, G. M. and R. Thompson, Lake sediment record of the geomagnetic secular variation in Britain during Holocene times, Geophys. J. Roy. astr. Soc., 65, 703-725, 1981.

Verosub, K. L., Depositional and post-depositional processes in the magnetization of sediments, Rev. Geophys. Space Phys., 15, 129-143, 1977.

Verosub, K. L., P. J. Mehringer, and P. Waterstrat, Holocene secular variation in western North America: palaeomagnetic record from Fish Lake, Harney County, Oregon, J. Geophys. Res., 91, 3609-3623, 1986. 